anales de psicología / annals of psychology

2020, vol. 36, $\mathrm{n}^{\circ} 2$ (mav), 262-270

https://doi.org/10.6018/analesps.366621
(C) Copyright 2020: Editum. Servicio de Publicaciones de la Universidad de Murcia. Murcia (Spain) ISSN print edition: 0212-9728. ISSN online edition (http://revistas.um.es/analesps): 1695-2294 Online edition License Creative Commons 4.0: BY-SA

\title{
The effects of children's self-educational aspiration and self-efficacy on mathematics achievement: A moderated chained mediation model
}

\author{
Tour Liu ${ }^{1,2,3}$, Xueming Chen ${ }^{1,2,3}$, Mengjun Liu ${ }^{1,2,3}$, Yingbin Zhang ${ }^{4}$, Tao Xin ${ }^{4 *}$, and Yehui Wang ${ }^{4}$ \\ 1 Key Research Base of Humanities and Social Sciences of the Ministry of Education, Academy of Psychology and Behavior, Tianjin Normal University, Tianjin 300387 (China). \\ 2 Faculty of Psychology, Tianjin Normal University, Tianjin 300387 (China). \\ 3 Center of Collaborative Innovation for Assessment and Promotion of Mental Health, Tianjin Normal University, Tianjin 300387 (China). \\ 4 Collaborative Innovation Center of Assessment toward Basic Education Quality, Beïing Normal University, Beijing 100875 (China).
}

\begin{abstract}
Título: Los efectos de la aspiración autoeducativa y la autoeficacia en el rendimiento en matemáticas de los niños: Un modelo de mediación en cadena moderado.

Resumen: Muchos estudios previos han discutido la influencia de factores extrínsecos (por ejemplo, entorno vital) en el logro académico de los niños de China occidental. El presente estudio se centró en cuatro factores no cognitivos, la aspiración autoeducativa, la autoeficacia, la motivación instrumental y la ansiedad, los cuales podrían afectar el logro matemático. El propósito de este estudio fue investigar los mecanismos por los cuales estos cuatro factores no cognitivos afectaron el logro matemático. Un total de 5774 estudiantes de primaria de $4^{\circ}$ y $5^{\circ}$ grado en el oeste de China participaron en este estudio. Se construyó un modelo de mediación encadenado moderado. Los resultados mostraron que la aspiración autoeducativa podría predecir positivamente el logro matemático. Sin embargo, la motivación instrumental y la ansiedad formaron una mediación encadenada entre la aspiración autoeducativa y el logro matemático, y predijeron negativamente el logro matemático. Además, la autoeficacia desempeñó un papel moderado en la relación entre la aspiración autoeducativa y la ansiedad.

Palabras clave: Aspiración autoeducativa; Autoeficacia; Motivación instrumental; Ansiedad; Logro matemático.
\end{abstract}

\section{Introduction}

Primary school stage is a crucial period for children's future achievement. There are a variety of factors that affect students' academic achievement, including cognitive factors and non-cognitive ones. In recent decades, psychologist and educationist are more interested in children's non-cognitive factors. Most previous researches discussed the influence of extrinsic factors on academic achievement like living environment, volumes of books, learning resources and so on (Zhang, Bian, Wang, \& Yuan, 2012; Zhang, Luo, Tao, Luo, \& Dong, 2015). A research of the Central Institute of Educational Science and Tian (2011) emphasized the important role of economic conditions and external resources. The result of their research showed that there were significant differences in the level of children's academic achievement between western China and eastern China. The level of children's academic achievement in eastern China was significantly higher than that of the western China in where economy was slightly behind. However, with the implementation of the western development strategy in China in recent

\section{* Correspondence address [Dirección para correspondencia]:}

Prof. Tao Xin: Collaborative Innovation Center of Assessment toward Basic Education Quality, Beijing Normal University, No. 19, XinjieKouWai St., HaiDian District, Beijing 100875, P. R. China Beijing, (China).

E-mail: xintao@bnu.edu.cn

(Article received: 8-3-2019; revised: 18-3-2019; accepted: 3-11-2019)
Abstract: Many previous studies have discussed the influence of extrinsic factors (e.g. living environment) on academic achievement of children from western China. The present study focused on four non-cognitive factors, self-educational aspiration, self-efficacy, instrumental motivation, and anxiety, which could affect mathematics achievement. The purpose of this study was to investigate the mechanisms how these four non-cognitive factors affected mathematics achievement. 5774 primary school students from fourth and fifth grade in western China participated in this study. A moderated chained mediation model was constructed. The results showed that self-educational aspiration could positively predict mathematics achievement. However, instrumental motivation and anxiety formed chained mediation between self-educational aspiration and mathematics achievement, and negatively predicted mathematics achievement. Besides, self-efficacy played a moderated role in the relationship between self-educational aspiration and anxiety.

Keywords: Self-educational aspiration; Self-efficacy; Instrumental motivation; Anxiety; Mathematics achievement.

years, these extrinsic materials or environment in western China improved tremendously. However, there were few studies concerning the relationship between non-cognitive factors and academic achievement from the psychological perspective of individuals. Therefore, it is of great importance to explore the relationships between students' own noncognitive factors and achievement in the context of western China.

Parental educational expectation is one of the most famous non-cognitive factors in previous studies. Parental educational expectation is the educational degree that parents expect their children will be (Yamamoto \& Holloway, 2010). Dozens of researchers have proved that parental educational expectation positively correlated with children's academic achievement (Aldous, 2006; Creed, Conlon, \& Zimmer-Gembeck, 2007; Schoon, Parsons, \& Sacker, 2004; Strand, 2011; Thiessen, 2007). Though parental educational expectation has positive correlation with students' academic attainment, it might not be a direct effect (Sy \& Schulenberg, 2005). Self-educational aspiration might be the key factor. Abiola (2014) believes that self-educational aspiration is a significant variable for predicting academic achievement. He explains that self-educational aspiration is an academic achievement motivation which will make students desire to succeed. Some researchers hold that students' academic achievement is affected by parental educational expectation via their self-aspiration (Nilsen, 2011; Rutchick, Smyth, Lo- 
poo, \& Dusek, 2009). In sum, most previous researches have discussed how parental expectation affects students' academic achievement, but few researches stand on the point of students themselves to explore how students' selfeducational aspiration directly affects their academic achievement.

Amongst the non-cognitive factors that affect academic achievement, learning motivation is another research hotspot. Learning motivation refers to a psychological tendency that stimulates and maintains individual learning behavior so that their learning desires can be satisfied (Schraw \& Sinatra 2004). Many researches indicate that students' learning motivation has significant and positive impacts on academic achievement (Singh, Granville, \& Dika, 2002). Uguroglu and Walberg (1979) read up a lot of research reports concerning the relationships between motivation and achievement. They find that the higher motivation level a student has, the higher achievement he will get. Motivation was considered as an integral factor in early studies, but it is furtherly divided into distinctive two types recently. Researchers from OECD (Organization for Economic Co-operation and Development) propose that learning motivation can be divided into intrinsic motivation and instrumental motivation. Intrinsic motivation refers to the fact that students learn something because they like it, while instrumental motivation is that students learn something for they think it useful (OECD, 2013; OECD, 2014). Although those two types of motivation and academic performance are closely related, instrumental motivation is the predominant factor when students are in primary education, in the meantime, their intrinsic motivation is rather weak (Giannelli \& Rapallini, 2018; OECD, 2013). Besides, Lens, Paixão and Herrera (2009) think that the instrumental motivation based on future goals is autonomous and of high quality. Therefore, it is worthwhile to investigate how primary school students' instrumental motivation will affect mathematics achievement.

Self-efficacy also affects academic achievement. Selfefficacy was proposed by Bandura (1977) and defined as an indicator of confidence in the competence of fulfilling a task. Bandura also pointed out that self-efficacy can enhance or weaken motivation. Individuals with high self-efficacy tend to choose challenging tasks and take efforts to fulfill them (Bandura, 1995). There is a significant positive correlation between self-efficacy and academic achievement (Loo \& Choy, 2013). Zajacova, Lynch and Espenshade (2005) also think that self-efficacy can predict academic success.

In addition, learning anxiety neither should be ignored. Many researchers have shown that learning anxiety has a crucial effect on academic achievement (Daniela, Margherita, Moè, Robert, \& Stephanie, 2018; Macher, Paechter, Papousek, \& Kai, 2012; Nunez-Pena, Suarez, Bono, 2013). El-Anzi and Owayed (2005) find that academic achievement is negatively correlated with anxiety. Tuncer and Dogan (2015) point out that students' anxiety strongly predicts their academic performance. Anxiety can negatively affect the academic achievement. When one's anxiety increases, his aca- demic achievement will decrease to a certain extent (Mohammad, Akhtar, Saira, \& Syeda, 2012). Beyond that, Ashcraft (2002) also believes that in the process of mathematics learning, highly anxious individuals would like to avoid mathematics, which will ultimately weaken their mathematics competence and lead to poor academic performance.

The simple relationships between academic achievement and motivation, academic achievement and self-efficacy, academic achievement and learning anxiety, are clear. However, these variables may take place together and correlate with each other. Many in-depth studies have been done. Some researchers are interested in self-efficacy. They find that self-efficacy can strongly predict the motivation (Skaalvik, Federici, \& Klassen, 2015). And self-efficacy could also predict academic performance (Kalaycioglu, 2015). Ahuja (2016) believes that self-efficacy together with selfeducational aspiration significantly and positively predict academic achievement. Many researchers concentrate on exploring the relationship between self-efficacy and educational anxiety. Some previous studies show that self-efficacy have significantly passive correlations with mathematics anxiety (Mcmullan, Jones, \& Lea, 2012; Razavi, Shahrabi, \& Siamian, 2017). Akin and Kurbanoglu (2011) also think that self-efficacy predicts mathematics anxiety negatively. All these studies above prompt us that self-efficacy may play a moderated role and anxiety may play a mediated role.

When researchers took motivation into consideration, the mechanism became more complex. Wigfield and Eccles (2000) believe that children with high educational aspiration tend to have stronger motivation. Taylor and Brown (1988) hold that positive self-aspiration could improve students' academic achievement via strengthening their learning motivation. While higher motivation would bring in higher level of anxiety (Essau, Leung, Conradt, Cheng, \& Wong, 2008). Thus, it seems like learning motivation and learning anxiety work as chained mediation between self-educational aspiration and academic achievement.

In general, owing to the lack of systematic researches on non-cognitive factors of primary students' achievement, the relationships of all these non-cognitive factors are still ambiguous. And the mechanism of the effects of all these noncognitive factors on mathematics achievement is unclear.

\section{The present research}

The purpose of this research was to investigate the noncognitive factors which could affect primary students' mathematics achievement in the context of western China, that is, to investigate the combined effects of primary school students' self-educational aspiration, self-efficacy, instrumental motivation and anxiety on mathematics achievement. In addition, the previous questionnaires for measuring selfefficacy, instrumental motivation, and anxiety were not suitable for evaluating primary students. So the new questionnaires were demanded. Based on the analyses above, this 
study made the following hypotheses: (1) Students' selfeducational aspiration and self-efficacy could significantly and positively predict mathematics achievement. (2) Students' instrumental motivation and anxiety acted as mediators between self-educational aspiration and mathematics achievement. Specifically, instrumental motivation and anxiety worked as the chained mediation. (3) Self-efficacy played a moderated role in the relationship between selfeducational aspiration and mathematics anxiety. The hypothetical model is presented in Figure 1.

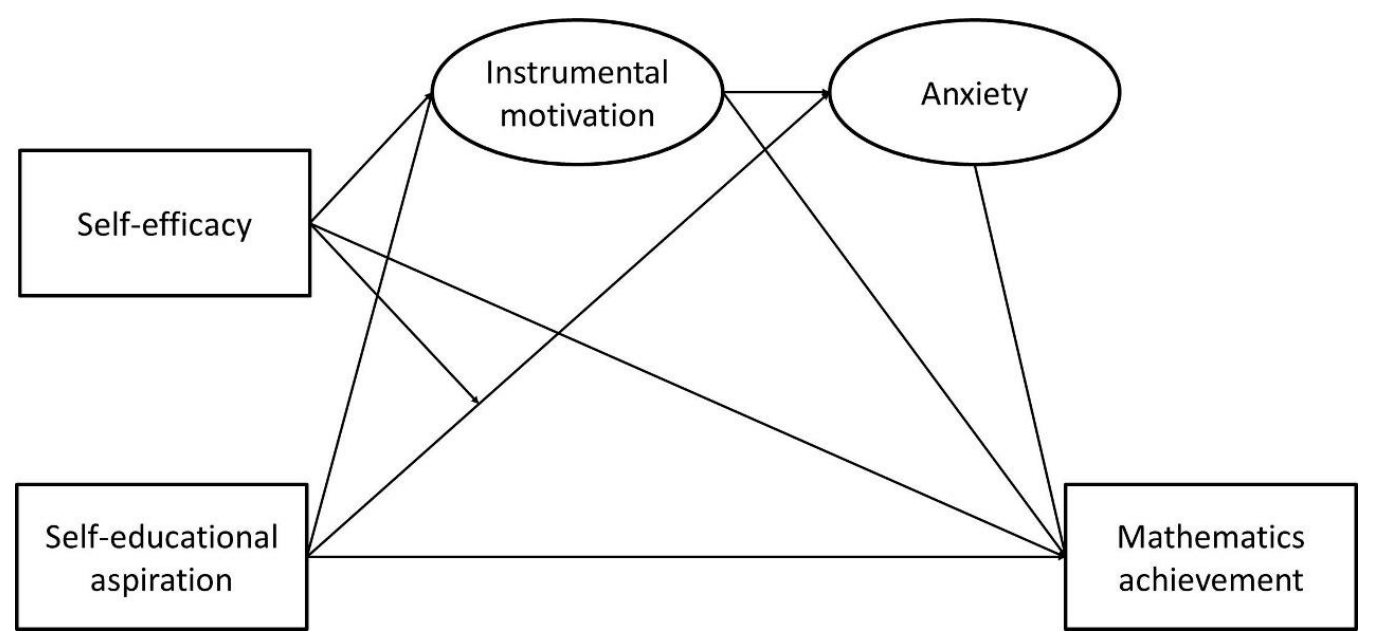

Figure 1. Hypothetical model.

\section{Methods}

\section{Participants}

The protocol of our research was approved by the ethics committee of the Academy of Psychology and Behavior, Tianjin Normal University. Our research did not involve cheating or other acts which would violate ethics. Because the measures used in the present study are more suitable for senior primary school students. 5776 fourth and fifth grade students including 2973 boys and 2803 girls completed the tests. Their average age was 11.50 (The average age of fourth grade students was 10.80 while the average age of fifth grade students was 12.16).

All participants came from five western provinces, which were selected conveniently from twelve provinces of western China. There were totally 60 schools included $(12$ schools per province). Two classes, one from grade 4 and another from grade 5 were chosen randomly. A dozen local teachers who can speak dialect were recruited from the local education commission, not from sample schools, together with postgraduate students of our university fulfilled the test administrations. Before the test administrations, test administrators would emphasize that all the data can be only used for research and the results would keep strictly confidential and would not be fed back to schools. Beyond that, the recruited local teachers would interpret in dialects if someone had problems with questionnaires to ensure that each student understood the meaning of the questionnaires. All questionnaires and materials were packed and mailed back to our university as soon as data collection was over.

\section{Measures}

Selfeducational Aspiration Questionnaire

The Self-educational Aspirations Questionnaire had only one item and was revised based on the item that measured students' educational aspiration developed by Zhang, Haddad, Torres and Chen (2011). The item was what is the highest degree of education you want to get? There were 6 options: 1 = primary school education, 2 = junior high school education, 3 = senior high school education (including vocational high school and technical secondary school), $4=$ university education (including college and bachelor degree), 5 = postgraduate education (including master and doctor degree), and Not Clear. If a student did not understand the concept of the options, he could choose the sixth option "Not Clear". If participants chose "Not Clear", the response to item would be regarded as a missing value.

\section{Instrumental Motivation Questionnaire}

Exploratory factor analysis was used to analyze PISA 2012 Mathematics Learning Motivation Scale in a pilot study, and the results showed that there were two factors: mathematics instrumental motivation and mathematics intrinsic motivation. The former concept was retained, and a new instrumental motivation questionnaire was developed to investigate primary school students' instrumental motivation in mathematical learning. There were four 4-points items in this scale (from $1=$ strongly disagree to $4=$ strongly agree). Instrumental motivation was processed as a latent variable in structural equation model (SEM). 


\section{Self-efficacy Scale}

Self-efficacy Scale was also newly developed for primary students' mathematical learning. Three 4-points items (from $1=$ strongly disagree to $4=$ strongly agree) were constructed. The standard scores of self-efficacy were treated as a manifest variable in SEM.

\section{Anxiety Scale}

Anxiety Scale which contained three 4-points items (from $1=$ strongly disagree to $4=$ strongly agree) was revised based on mathematics anxiety scale from OECD (2014). It was processed as a latent variable in SEM.

\section{Mathematics Achievement Test}

The Mathematics Achievement Test was compiled by the primary school teachers and educational measurement experts from the Mathematics Curriculum Standards of Compulsory Education. It could evaluate students' mathematics achievement by using 30 multiple-choice items from four dimensions: algebra, space and graphics, statistics and pro- bability, practice and integrated application. The mean of item difficulties was 0.55 , and the mean of item discriminations was 0.25 . The standard scores of mathematics achievement were treated as a manifest variable in SEM.

\section{Data analysis}

IBM SPSS 24.0 was used to preprocess data and do descriptive statistics. Mplus 8.0 was used to run the multiple latent mediated models.

\section{Results}

\section{Questionnaires verification}

\section{Reliability and validity of scales}

The Self-educational Aspirations Questionnaire had only one item which was revised based on the measure tool developed by Zhang, Haddad, Torres and Chen (2011) which had been proved to be available. And the frequency of participants' response to self-educational aspiration is as follow:

Table1. Frequency of response to self-educational aspiration.

\begin{tabular}{lccc}
\hline & Frequency & Percentage & Accumulated percentage \\
\hline Primary school education & 84 & 1.5 & 1.5 \\
Junior high school education & 159 & 2.8 & 4.2 \\
Senior high school education & 335 & 5.8 & 10 \\
University education & 2014 & 34.9 & 44.9 \\
Postgraduate education & 2650 & 45.9 & 90.8 \\
Missing values & 534 & 9.2 & 100 \\
Sum & 5776 & 100 & \\
\hline
\end{tabular}

In addition, self-efficacy scale, instrumental motivation questionnaire, and anxiety scale were newly developed specially for mathematical learning of primary school students from western China. So the reliability and validity of these three scales have been verified firstly in the present study. The internal consistency coefficients $(a)$ of these three scales were .63 (anxiety scale), .69 (self-efficacy scale) and .72 (instrumental motivation questionnaire). They were good and acceptable considering the short test length (Green \& Yang, 2009; Morera \& Stokes, 2016).
Besides, Exploratory Factor Analysis were conducted, the results showed that the unidimensionality of the scales were well satisfied and the confirmatory factor analysis also verified the structure validity, the CFI, TLI and RMSE $A$ indicated good fit of structure of three scales. The internal consistency coefficient $(\alpha)$, explanation rate of the first factor (EFA), and the model fitting index (CFA) of three scales are as follows:

Table 2. Reliability and validity of three new scales

\begin{tabular}{lcccccc}
\hline Scales & $a$ & Total & Eigenvalues \% of Variance & RMSEA & CFI & TLI \\
\hline Instrumental Motivation Scale & 0.72 & 2.20 & 54.98 & 0.05 & 0.97 & 0.95 \\
Self-efficacy Scale & 0.69 & 1.85 & 61.64 & 0.00 & 1.00 & 1.00 \\
Anxiety Scale & 0.63 & 1.72 & 57.23 & 0.00 & 1.00 & 1.00 \\
\hline
\end{tabular}

Besides, the mathematics achievement test used in present study was also used in another study of western China which had verified the reliability and validity of it (Wang, Yang, Zhang, Wang, Liu, \& Xin, 2018). In present study, the reliability and validity indices of mathematics achievement test were calculated. The coefficient of internal consistency was 0.79 . Two mathematics teacher and three experts engaged in mathematical teaching practice in primary schools were invited to evaluate the item content. The inter-rater reliability was 0.93 , which proved that this mathematics achievement test was good. 
Item difficulties of mathematics achievement test

Item difficulties of mathematics achievement test were also calculated (see Figure 2). Figure 2 shows that more than half of the students could not reach the right answers to 14 out of 30 items.

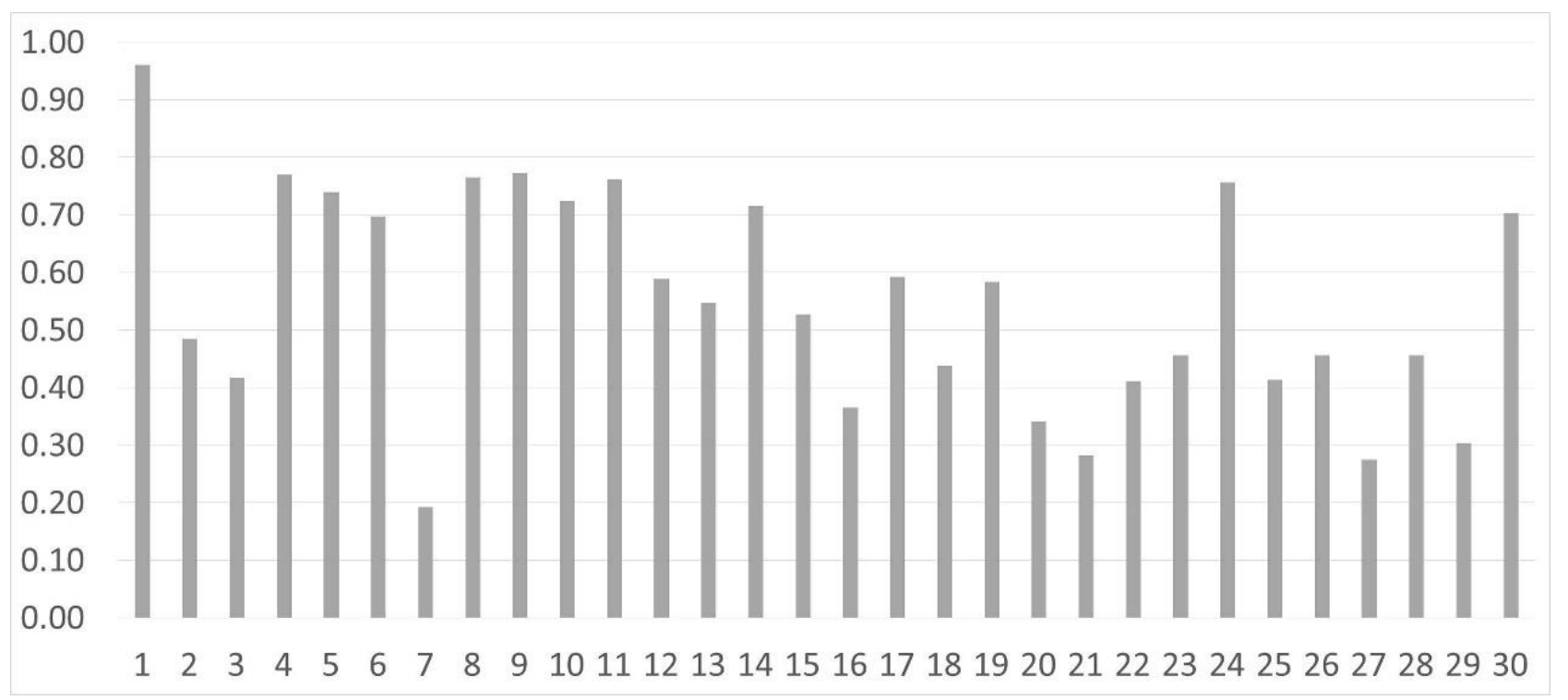

Figure 2. Item difficulties of mathematics achievement test.

\section{Common method bias test}

Due to the artificial covariation between the predictor variable and the dependent variable was caused by the same raters, the same item context, and the characteristics of the item themselves, Harman's single factor test was used to test common method bias. The results of Harman's single factor test showed that there were a total of 2 factors with eigenvalues greater than 1 , and the first factor explained a variance of only $31.36 \%$, which was less than the critical value of $40 \%$, indicating that there was no common method bias.

\section{Descriptive statistics analysis and correlation analysis}

Descriptive statistics analysis and correlation analysis were conducted. The descriptive statistics and the correlation matrix of all variables are shown in Table 3 .

Table 3. Descriptive statistics results and correlation matrix.

\begin{tabular}{|c|c|c|c|c|c|}
\hline & $\begin{array}{c}\text { Self-educational } \\
\text { aspiration }\end{array}$ & $\begin{array}{c}\text { Instrumental } \\
\text { motivation }\end{array}$ & Self-efficacy & Anxiety & $\begin{array}{l}\text { Mathematics } \\
\text { achievement }\end{array}$ \\
\hline Self-educational aspiration & - & & & & \\
\hline Instrumental motivation & $.16^{* *}$ & - & & & \\
\hline Self-efficacy & $.08^{* *}$ & $.35^{* *}$ & - & & \\
\hline Anxiety & $-.09 * *$ & $.12^{* *}$ & $-.03 *$ & - & \\
\hline Mathematics achievement & $.22 * *$ & $.16^{* *}$ & $.14^{* *}$ & $-.19 * *$ & - \\
\hline Mean & 4.33 & 3.51 & 2.90 & 2.60 & 16.11 \\
\hline $\mathrm{SD}$ & 0.85 & 0.58 & 0.73 & 0.82 & 5.14 \\
\hline
\end{tabular}

Note: $* p<.05, * * p<.01, * * * p<.001$.

The results indicated that self-educational aspiration, selfefficacy, mathematics achievement, and instrumental motivation were positively related to each other $(p<.01)$; selfeducational aspiration, self-efficacy, mathematics achievement were negatively correlated with anxiety $(p<.01)$; instrumental motivation and anxiety were positively related $(p<$ $.01)$. These results provided certain prerequisites for the following modeling processes.

\section{Gender Differences}

Previous research suggested that there were significant differences between males and females (Spelke \& Elizabeth, 2005). To exclude the gender effect, difference tests were conducted on each variable in each grade (fourth and fifth grade). The results are shown in Table 4 and Table 5 . 
Table 4. Gender differences (4 th grade) in all variables.

\begin{tabular}{ccccccc}
\hline & $t$ & $d f$ & sig & Mean Difference & Std. Error Difference & Cohen's d \\
\hline Self-educational aspirations & 0.58 & 2783 & .562 & 0.03 & 0.05 & 0.02 \\
Self-efficacy & -3.43 & 2532 & .001 & -0.29 & 0.09 \\
Instrumental motivation & 3.13 & 2528 & .002 & 0.29 & 0.09 \\
Anxiety & 4.32 & 2595 & .000 & 0.42 & 0.14 & 0.12 \\
Mathematics achievement & 0.44 & 2789 & .658 & 0.08 & 0.18 \\
\hline
\end{tabular}

In fourth grade, there were significant differences in gender on self-efficacy, instrumental motivation and anxiety, but the effect sizes were very small $(0.14,0.12$ and 0.17$)$. Moreover, gender had no significant influence on self- educational aspirations and mathematics achievement. These results indicated that the gender differences on casual variables would not result in differences on mathematics achievement in fourth grade.

Table 5. Gender differences (5 th grade) in all variables.

\begin{tabular}{ccccccc}
\hline & $t$ & $d f$ & sig & Mean Difference & Std. Error Difference & Cohen's \\
\hline Self-educational aspirations & -1.88 & 2802 & .060 & -0.08 & 0.04 & 0.07 \\
Self-efficacy & -4.89 & 2800 & .000 & -0.41 & 0.08 & 0.18 \\
Instrumental motivation & 3.52 & 2757 & .000 & 0.32 & 0.09 & 0.09 \\
Anxiety & 6.81 & 2799 & .000 & 0.61 & 0.13 & 0.20 \\
Mathematics achievement & 2.14 & 2973 & .032 & 0.42 & 0.08 \\
\hline
\end{tabular}

In fifth grade, although the gender differences on mathematics achievement was significant, there were no significant differences on self-educational aspirations which showed that the influence of gender on mathematics achievement was not originated from independent variable selfeducational aspirations. Furthermore, the effect size of gender on mathematics achievement was tiny (0.08). Therefore, the gender differences were ignored in the following analyses.

\section{Grade Differences}

In addition, grade differences were tests on each variables. The results are shown in Table 6 .

Table 6. Grade differences in all variables.

\begin{tabular}{ccccccc}
\hline & $t$ & $d f$ & sig & Mean Difference & Std. Error Difference & Cohen's d \\
\hline Self-educational aspirations & 2.14 & 5596 & .032 & 0.07 & 0.03 & 0.06 \\
Self-efficacy & -6.08 & 5306 & .000 & -0.36 & 0.06 & 0.17 \\
Instrumental motivation & -2.47 & 5303 & .014 & -0.16 & 0.07 & 0.07 \\
Anxiety & -0.27 & 5415 & .784 & -0.02 & 0.07 & 0.14 \\
Mathematics achievement & -18.95 & 5767 & .000 & -2.56 & 0.50 \\
\hline
\end{tabular}

There were no significant differences in grade on anxiety, while there were significant differences on self-educational aspiration, self-efficacy, instrumental motivation (effect sizes was small: $0.06,0.17,0.07)$ and mathematics achievement. However, the grade differences were not the original goal of this study. They would not be discussed below.

\section{A moderated chained mediation model}

A latent variable SEM was run upon the hypothetical model illustrated above. And the final model fitted well $\left(\chi^{2} / d f=11.78\right.$, RMSE $A=0.04, C F I=0.96, T L I=0.93$, $S R M R=0.03)$.

Figure 3 displays the final model with standardized path coefficients. Both self-educational aspiration and selfefficacy can positively predict instrumental motivation $(r=$
$0.14, p<.01 ; r=0.37, p<.01)$. And these three variables can significantly predict the mathematics achievement $(r=$ $0.15, p<.01 ; r=0.08, p<.01 ; r=0.16, p<.01)$. Selfeducational aspiration negatively predicts anxiety $(r=-0.10, p$ $<.01)$, while anxiety predicts mathematics achievement negatively $(r=-0.29, p<.01)$, which suggests that anxiety may play a mediated role between self-educational aspiration and mathematics achievement. Additionally, instrumental motivation can positively predict anxiety $(r=0.20, p<.01)$, which suggests that instrumental motivation and anxiety work as the chained mediation.

In addition, self-efficacy predicts anxiety negatively $(r=$ $0.14, p<.01)$ and its interaction with self-educational aspiration also affects anxiety negatively $(r=-0.13, p<.01)$. In other words, self-efficacy plays a moderated role in the relationship between self-educational aspiration and anxiety. 


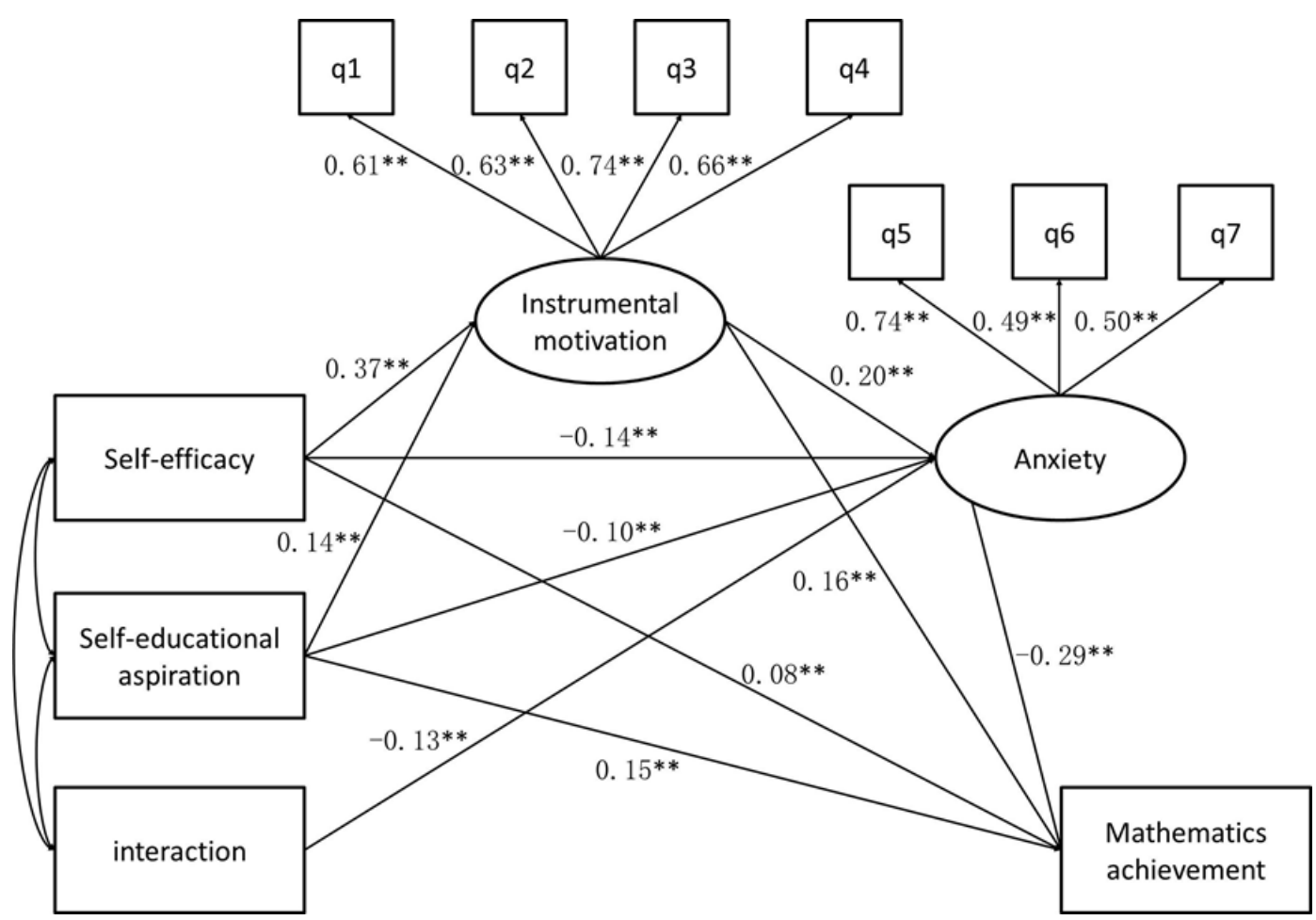

Figure 3. The moderated chained mediation model with standardized estimates.

Table 7. The effect sizes of direct and indirect mediation.

\begin{tabular}{lcc}
\hline Effects & $B$ & Proportion \\
\hline $\mathrm{SA} \rightarrow \mathrm{MA} \rightarrow$ achievement & 0.029 & $13.87 \%$ \\
$\mathrm{SA} \rightarrow \mathrm{IM} \rightarrow$ achievement & 0.022 & $10.53 \%$ \\
$\mathrm{SA} \rightarrow \mathrm{IM} \rightarrow \mathrm{MA} \rightarrow$ achievement & -0.008 & $3.83 \%$ \\
$\mathrm{SA} \rightarrow$ achievement & 0.150 & $71.77 \%$ \\
$\mathrm{SA} \mathrm{Total}$ & 0.209 & \\
$\mathrm{SE} \rightarrow \mathrm{MA} \rightarrow$ achievement & 0.041 & $20.40 \%$ \\
$\mathrm{SE} \rightarrow \mathrm{IM} \rightarrow$ achievement & 0.059 & $29.35 \%$ \\
$\mathrm{SE} \rightarrow \mathrm{IM} \rightarrow \mathrm{MA} \rightarrow$ achievement & -0.021 & $10.45 \%$ \\
$\mathrm{SE} \rightarrow$ achievement & 0.080 & $39.80 \%$ \\
$\mathrm{SE}$ Total & 0.201 & \\
\hline
\end{tabular}

Note: $\mathrm{SA}=$ self-educational aspirations; $\mathrm{MA}=$ anxiety; $\mathrm{IM}=$ instrumental motivation; $\mathrm{SE}=$ self-efficacy.

$* p<.05, * * p<.01, * * * p<.001$.

Furtherly, Table 7 presents the indirect effect sizes and direct effect sizes. As presented, both indirect effect size of student's self-educational aspiration and self-efficacy on mathematics achievement via instrumental motivation and anxiety are significant. In the relationship between selfeducational aspirations and mathematics achievement, instrumental motivation explain $10.53 \%$ of variance, and anxiety explains $13.87 \%$ of variance, instrumental motivation together with anxiety explain $28.23 \%$ of variance. Likewise, in the relationship between self-efficacy and mathematics achievement, instrumental motivation explains $29.35 \%$ of variance, and anxiety explains $20.40 \%$ of variance, instrumental motivation together with anxiety explain $60.20 \%$ of variance.

\section{Discussion}

It can be seen from Figure 2 that the mathematics achievement levels of primary school students in western China are less than satisfactory. To figure out what factors can enhance children's mathematics achievement from western China, the present study took self-educational aspiration, self-efficacy, instrumental motivation, and anxiety into consideration, and proposed a moderated chained mediation model. This model provided a proper mechanism about how children's selfeducational aspiration affects mathematics achievement.

The model results showed that either students' selfeducational aspiration or self-efficacy would positively predict mathematics achievement not only in direct way but also in indirect way via instrumental motivation. The effect of self-educational aspiration had been proved by Purnami, Widodo, and Prahmana (2018). Students with high levels of self-educational aspirations were more likely to have high instrumental motivations which would get their mathematics performances improved. This is because higher selfeducational aspirations may stimulate learning motivation, and then the mathematics achievement rises. But things turn into their opposites when they reach the extreme, as the level of instrumental motivation enhances, students will get a stronger sense of anxiety which may lead to poor mathematics achievement (Recber \& Isiksal, 2018; Wu, Barth, Amin, Malcarne, \& Menon, 2012). That means self-educational aspirations only can positively affect mathematics achievement when it is moderate. 
In addition, consistent with previous studies, self-efficacy plays a crucial role in mathematics achievement (Akin \& Kurbanoglu, 2011; Kalaycioglu, 2015). Self-efficacy can predict individual mathematics achievement directly and predict it indirectly via the chain-mediating role of instrumental motivation and anxiety. According to self-efficacy theory, individual behavior is codetermined by outcome expectation and efficacy expectation (Bandura, 1977). Students with a high level of self-efficacy are more likely to believe they can success if they want, so students with high self-efficacy always have higher instrumental motivation, but higher motivation brings higher level of anxiety which may decrease students' mathematics achievement (Khalaila, 2015). It follows that instrumental motivation plays an important role in the relationship. Thus, students should maintain moderate learning motivation and do not put too much pressure on themselves.

The results of this study also indicated that children's self-efficacy played a moderated role in the relationships between self-educational aspirations and anxiety. Which means when students' self-educational aspirations are high, those who with lower self-efficacy may be more likely to be nervous and anxious, while those who with higher selfefficacy are less likely to produce excessive anxiety $\mathrm{Xu}, \mathrm{Lou}$, Wang, \& Pang, 2017). This is probably because students with higher self-efficacy consider the bad situations as an opportunity to exercise personal abilities and make progress. When situation gets worse, they will strengthen and sustain their efforts. On the contrary, students with lower self-efficacy always disbelieve in their abilities and are more likely to give up when they encounter difficulties (Stetz, Stetz, \& Bliese, 2006).

\section{References}

Abiola, J. (2014). Impact of educational aspirations on vocational choices of the female secondary school students in Ondo West local government area of the Ondo State, Nigeria. European Scientific Journal, 1, 224-233. http://eujournal.org/index.php/esj/article/view/4773/4578

Ahuja, A. (2016). A Study of Self-Efficacy among Secondary School Students in relation to Educational Aspiration and Academic Achievement. Education and Applied Social Sciences, 7, 275-283. https://doi.org/10.5958/2230-7311.2016.00048.9

Akin, A., \& Kurbanoglu, I. N. (2011). The relationships between math anxiety, math attitudes, and self-efficacy: A structural equation model. $\begin{array}{llll}\text { Studia Psychologica, 53, 263-273. } & \text { 53 }\end{array}$ https://search.proquest.com/docview/901145402?accountid=17142

Aldous, J. (2006). Family, Ethnicity, and Immigrant Youths' Educational Achievements. Journal of Family Issues, 27, 1633-1667. https://doi.org/10.1177/0192513X06292419

Ashcraft, M. H. (2002). Math anxiety: Personal, educational, and cognitive consequences. Current Directions in Psychological Science, 11, 181-185. https://doi.org/10.1111/1467-8721.00196

Bandura, A. (1977). Self-efficacy: Toward a unifying theory of behavioral change. Psychological Review, 2, 191-215. https://doi.org/10.1016/01466402(78)90002-4

Bandura, A. (1995). Self-efficacy in changing societies. England: Cambridge University.

Creed, P. A., Conlon, E. G., \& Zimmer-Gembeck, M. J. (2007). Career barriers and reading ability as correlates of career aspirations and expecta-
What should be pointed out is that this study only explored the effects of non-cognitive factors on primary school students' mathematics achievement, whether the same or similar effects exist in the population of other ages remain to be investigated. Furthermore, the grade differences between fourth grade and fifth grade on self-educational aspiration, self-efficacy, and instrumental motivation came up. A longitudinal study can be conducted to explore the changes of these factors in future. Additionally, this study revealed a psychological mechanism based on children from western China. Although some inferences can be drawn from results. The differences between western China and eastern China on psychological mechanism cannot be concluded, and a comparative study is needed.

\section{Conclusions}

Based on the research results above, the following conclusions can be drawn. (1) Both children's self-efficacy and selfeducational aspirations have directly positive effects on mathematics achievement. (2) Self-educational aspirations and self-efficacy have indirectly negative effects on mathematics achievement via the chained mediation of instrumental motivation and anxiety. (3) The relationships between selfeducational aspirations and anxiety were moderated by children's self-efficacy.

Disclosure statement: No potential conflict of interest was reported by the authors.

Acknowledgments.- This work was supported by the Projects of Philosophy and Social Sciences Research, Ministry of Education, China (Grant No. 18YJC190013).

tions of parents and their children. Journal of Vocational Behavior, 70, 242258. https://doi.org/ 10.1016/j.jvb.2006.11.001

Daniela, R., Margherita, B., Moè A., Robert, S., \& Stephanie, L. (2018). Enjoyment, boredom, anxiety in elementary schools in two domains: Relations with achievement. The Journal of Experimental Education, 1-21. https://doi.org/10.1080/00220973.2018.1448747

El-Anzi, \& Owayed, F. (2005). Academic achievement and its relationship with anxiety, self-esteem, optimism, and pessimism in Kuwaiti students. Social Behavior and Personality: an international journal, 33, 95-104. https://doi.org/10.2224/sbp.2005.33.1.95

Essau, C. A., Leung, P. W. L., Conradt, J., Cheng, H., \& Wong, T. (2008). Anxiety symptoms in Chinese and German adolescents: their relationship with early learning experiences, perfectionism, and learning motivation. Depression and anxiety, 25, 801-810. https://doi.org/10.1002/da.20334

Giannelli, G. C., \& Rapallini, C. (2018). Parental occupation and children's school outcomes in math. Social Science Electronic. https://ideas.repec.org/p/frz/wpaper/wp2018_06.rdf.html

Green, S. B., \& Yang, Y. Y. (2009). Commentary on coefficient alpha: A cautionary tale. Psychometrika, 74, 121-135. https://doi.org/10.1007/s11336-008-9098-4

Kalaycioglu, D. B. (2015). The influence of socioeconomic status, selfefficacy, and anxiety on mathematics achievement in England, Greece, Hong Kong, the Netherlands, Turkey, and the USA. Kuram Ve Uygulamada Egitim Bilimleri, 15, 1391-1401. https://doi.org/10.12738/estp.2015.5.2731 
Khalaila, R. (2015). The relationship between academic self-concept, intrinsic motivation, test anxiety, and academic achievement among nursing students: mediating and moderating effects. Nurse Education Today, 35, 432-438. https://doi.org/10.1016/j.nedt.2014.11.001

Lens, W., Paixão, M. P., \& Herrera, D. (2009). Instrumental motivation is extrinsic motivation: So what???. Psychologica, 50, 21-40. https://doi.org/10.14195/1647-8606_50_2

Loo, C. W., \& Choy, J. (2013). Sources of Self-Efficacy Influencing Academic Performance of Engineering Students. American Journal of Educational Reseach, 3, 86-92. https://doi.org/10.12691/education-1-3-4

Macher, D., Paechter, M., Papousek, I., \& Kai, R. (2012). Statistics anxiety, trait anxiety, learning behavior, and academic performance. European Journal of Psychology of Education, 27, 483-498. https://doi.org/10.1007/s10212-011-0090-5

Mcmullan, M., Jones, R., \& Lea, S. (2012). Math anxiety, self-efficacy, and ability in British undergraduate nursing students. Research in Nursing and Health, 35, 178-186. https://doi.org/10.1002/nur.21460

Mohammad, N., Akhtar, A., Saira, M., \& Syeda U. Z. (2012). Impact of Anxiety on the Academic Achievement of Students. International Online Journal of Educational Sciences, 4, 519-528. https://doi.org/622b/522db18af95ad25959f6cf094bd7219c6e10

Morera, O. F., \& Stokes, S. M. (2016). Coefficient $\alpha$ as a measure of test score reliability: Review of 3 popular misconceptions. American Journal of Public Health, 106, 458-461. https://doi.org/10.2105/ajph.2015.302993

Nilsen, C. (2011). The role of parent expectations on adolescent educational $\begin{array}{llll}\text { aspirations. } & \text { Educational } & \text { Studies, } & 37,\end{array}$ https://doi.org/10.1080/03055691003728965

Nunez-Pena, M. I., Suarez, P. M., \& Bono, R. (2013). Effects of math anxiety on student success in higher education. International Journal of Educational Research, 58, 36-43. https://doi.org/10.1016/j.ijer.2012.12.004

Organization for Economic Co-operation and Development. (2013). PISA 2012 results: Ready to learn: Students' engagement, drive and selfbeliefs (Volume III).

Organization for Economic Co-operation and Development. (2014). PISA 2012 Technical Report.

Purnami, A. S., Widodo, S. A., \& Prahmana, R. C. I. (2018). The effect of team accelerated instruction on students' mathematics achievement and learning motivation. Journal of Physics Conference Series, 948, 1-6. https://doi.org/10.1088/1742-6596/948/1/012020

Razavi, S., Shahrabi, A., \& Siamian, H. (2017). The relationship between research anxiety and self-efficacy. Materia Socio Medica, 29, 247-250. https://doi.org/10.5455/msm.2017.29.247-250

Recber, S., \& Isiksal, M. (2018). Investigating self-efficacy, anxiety, attitudes and mathematics achievement regarding gender and school type. Anales De Psicología, 34, 41-51. https://doi.org/10.6018/analesps.34.1.229571

Rutchick, A. M., Smyth, J. M., Lopoo, L. M., \& Dusek, J. B. (2009). Great Expectations: The Biasing Effects of Reported Child Behavior Problems on Educational Expectancies and Subsequent Academic Achievement. Journal of Social \& Clinical Psychology, 28, 392-413. https://doi.org/10.1521/jscp.2009.28.3.392

Schoon, I., Parsons, S., \& Sacker, A. (2004). Socioeconomic Adversity, Educational Resilience, and Subsequent Levels of Adult Adaptation. Journal of Adolescent Research, 19, 383-404. https://doi.org/10.1177/0743558403258856

Schraw, G., \& Sinatra, G. M. (2004). Epistemological development and its impact on cognition in academic domains. Contemporary Educational Psychology, 29, 95-102. https://doi.org/10.1016/j.cedpsych.2004.01.005

Singh, K., Granville, M., \& Dika, S. (2002). Mathematics and Science Achievement: Effects of Motivation, Interest, and Academic Engagement. Journal of Educational Research, 95, 323-332. https://doi.org/10.1080/00220670209596607

Skaalvik, E. M., Federici, R. A., \& Klassen, R. M. (2015). Mathematics achievement and self-efficacy: Relations with motivation for mathema- tics. International Journal of Educational Research, 72, 129-136. https://doi.org/10.1016/j.ijer.2015.06.008

Spelke, \& Elizabeth, S. (2005). Sex differences in intrinsic aptitude for mathematics and science: A critical review. American Psychologist, 60, 950958. https://doi.org/10.1037/0003-066X.60.9.950

Stetz, T. A., Stetz, M. C., \& Bliese, P. D. (2006). The importance of selfefficacy in the moderating effects of social support on stressor-strain relationships. Work \& Stress, 101, 49-59. https://doi.org/10.1080/02678370600624039

Strand, S. (2011). The limits of social class in explaining ethnic gaps in educational attainment. British Educational Research Journal, 37, 197-229. https://doi.org/10.1080/01411920903540664

Sy, S., \& Schulenberg, J. (2005). Parent beliefs and children's achievement trajectories during the transition to school in Asian American and European American families. International Journal of Behavioral Development 29, 505-515. https://doi.org/10.1177/01650250500147329

Taylor, S. E., \& Brown, J. D. (1988). Illusion and well-being: A social psychological perspective on mental health. Psychological Bulletin, 103, 193-210. https://doi.org/10.1037/0033-2909.103.2.193

The Research Group from Central Institute of Educational Science \& Tian, H. (2011). The survey report about academic achievement of sixth grade students in China. Educational Research, 1, 27-38.

Thiessen, V. (2007). The impact of factors on trajectories that lead to a high school diploma and to participation in post-secondary education among those with low reading competencies at age 15 https://www.worldcat.org/oclc/802319503

Tuncer, M., \& Dogan, Y. (2015). Effect of foreign language classroom anxiety on Turkish University students' academic achievement in foreign language learning. Journal of Education \& Training Studies, 3, 14-19. https://doi.org/10.11114/jets.v3i6.998

Uguroglu, M. E., \& Walberg, H. J. (1979). Motivation and achievement: A quantitative synthesis. American Educational Research Journal, 16, 375-389. https://doi.org/10.3102/00028312016004375

Wang, Y. H., Yang, Z. X., Zhang, Y. B., Wang, F. M., Liu, T., \& Xin, T. (2018). The Effect of Social-Emotional Competency on Child Development in Western China. Frontiers in Psychology, 10, 1-10. https://doi.org/10.3389/fpsyg.2019.01282

Wigfield, A., \& Eccles, J. S. (2000). Expectancy-value theory of achievement motivation. Contemporary Educational Psychology, 25, 68-81. https://doi.org/10.1006/ceps.1999.1015

Wu, S. S., Barth, M., Amin, H., Malcarne, V., \& Menon, V. (2012). Math anxiety in second and third graders and its relation to mathematics achievement. Frontiers in Psychology, 3, 162-172. https://doi.org/10.3389/fpsyg.2012.00162

Xu, X., Lou, L., Wang, L., \& Pang, W. (2017). Adolescents' perceived parental psychological control and test anxiety: Mediating role of academic self-efficacy. Social Behavior and Personality, 45, 1573-1583. https://doi.org/10.2224/sbp.6754

Yamamoto, Y., \& Holloway, S. D. (2010). Parental Expectations and Children's Academic Performance in Sociocultural Context. Educational Psychology Review, 22, 189-214. https://doi.org/10.1007/s10648-0109121-z

Zajacova, A., Lynch, S. M., \& Espenshade, T. J. (2005). Self-Efficacy, Stress, and Academic Success in College. Research in Higher Education, 46, $677-$ 706. https://doi.org/10.1007/s11162-004-4139-z

Zhang, Q. R., Bian Y. F., Wang Y. H., \& Yuan C. Y. (2012). The impact of school education environment and resources on students' academic achievement. Education Research, 8, 32-40.

Zhang, Y., Haddad, E., Torres, B., \& Chen, C. (2011). The reciprocal relationships among parents' expectations, adolescents' expectations, and adolescents' achievement: A two-wave longitudinal analysis of the NELS data. Journal of Youth and Adolescence, 40, 479-489. https://doi.org/10.1007/s10964-010-9568-8

Zhang, Y. Y., Luo, F., Tao, S., Luo, L., \& Dong, Q. (2015). The impact of family social economic status and parents' educational investment on migrant children's academic achievement. Psychological Science , 1, 19-26 